\title{
EKSTRAKSI DAN KARAKTERISASI GELATIN TULANG KAMBING KACANG MENGGUNAKAN NEUTRASE
}

\author{
Dellen N. Matulessy ${ }^{122}$ *), Yuny Erwanto ${ }^{2)}$, Nurliani' ${ }^{2)}$, Edy Suryanto ${ }^{2)}$ \\ 1) Politeknik Perdamaian Halmahera, Tobelo, Halmahera Utara, Maluku Utara 97762 \\ dan Mahasiswa Program studi Peternakan, Fakultas Peternakan, Universitas Gadjah Mada, Yogyakarta 55281 \\ 2) Program studi Peternakan, Fakultas Peternakan, Universitas Gadjah Mada, Yogyakarta 55281 \\ *Email : mdellen18@gmail.com
}

\begin{abstract}
ABSTRAK
Penelitian ini bertujuan untuk mengevaluasi karakteristik gelatin tulang kambing Kacang yang diekstraksi secara enzimatik menggunakan neutrase ${ }^{\circledR}$, dengan perlakuan konsentrasi enzim yang berbeda, yaitu GTK-N0 (gelatin dengan neutrase $0 \%$ ), GTK-N1 (Gelatin dengan neutrase 0,25 \%), GTK-N2 (Gelatin dengan neutrase 0,5\%) dan GTK-N3 (Gelatin dengan neutrase 0,75\%). Tulang yang digunakan adalah tulang kambing kacang umur 6 sampai 12 bulan. Rancangan penelitian yang digunakan adalah rancangan acak lengkap pola searah dengan 4 perlakuan konsentrasi enzim dengan 5 ulangan. Peubah yang diamati adalah yield, analisis proksimat dilakukan pada tulang kambing dan gelatin (kadar air, abu, lemak dan protein kasar), $\mathrm{pH}$, kekuatan gel, viskositas, gugus fungsional FTIR gelatin. Hasil penelitian menunjukan bahwa neutrase dengan konsentrasi $0,25 \%$ berpengaruh nyata terhadap karakteristik gelatin tulang kambing Kacang. Kesimpulan dari penelitian ini adalah neutrase dapat digunakan untuk ekstraksi tulang kambing Kacang dengan menghasilkan karakteristik gelatin yang dapat digunakan untuk aplikasi pangan.
\end{abstract}

Kata kunci: Ekstraksi dan karakterisasi gelatin, tulang kambing Kacang, neutrase

\section{EXTRACTION AND CHARACTERIZATION OF GELATIN DERIVATE FROM KACANG GOAT BONE BY NEUTRASE}

\begin{abstract}
This study aims was to evaluate the characteristics of the gelatine derivate from Kacang goat bone extracted enzymatically using neutrase at different enzyme concentrations. The neutrase treatments, namely GTK-N0 (gelatin with neutrase 0\%), GTK-N1 (Gelatin with 0.25\% neutrase), GTK-N2 (Gelatin with neutrase 0.5\%) and GTK-N3 (Gelatin with neutrase 0,75\%). The bones sample used the bones from local Kacang goat aged 6 to 12 months. The study used was a randomized complete design (Oneway ANOVA) with 4 enzyme concentration treatments with 5 replications each treatment. The parameters observed were gelatin yields, the proximate analysis was performed on goat bones and gelatin (water content, ash, fat, and crude protein), $\mathrm{pH}$, gel strength, viscosity, and functional groups of gelatin FTIR. The results showed that the application of the neutrase enzyme at the $0.25 \%$ level had the significant effect on the characteristics of the gelatin produced. The conclusion of this study neutrase can be used for enzymatically extracting gelatin from the bones of local Kacang goat and produced the gelatin characteristics that can be used for food applications.
\end{abstract}

Key words: Extraction and characterization of gelatin, bone of Kacang goat, neutrase

\section{PENDAHULUAN}

Gelatin merupakan salah satu senyawa protein penting yang memiliki banyak manfaat, khususnya dalam industri pangan (Liu et al., 2012). Gelatin dapat diperoleh melalui ekstraksi parsial kolagen yang bersumber dari daging, tulang dan kulit dari berbagai jenis hewan. Gelatin dari sumber mamalia lebih disukai karena sifat fisikokimia dan fungsionalnya yang unggul (Shyni et al., 2014). Di Indonesia, kebutuhan gelatin nasional sangat tergantung dengan impor. Badan Pusat Statistik (BPS) melaporkan bahwa pada tahun 2017 Indonesia mengimpor lebih dari 3.000 ton gelatin untuk memenuhi kebutuhan gelatin dalam negeri dan diperkirakan akan terus bertambah ke depannya. Gelatin impor memiliki kualitas dan sumber bahan baku yang sangat bervariasi, sehingga sering menimbulkan keraguan terhadap penerimaan masyarakat terutama sebagai produk makanan. Atas dasar itulah diperlukan eksplorasi sumber daya lokal dengan metode ekstraksi 
yang tepat dalam menyediakan gelatin yang terjamin, berkualitas, dan dapat diterima semua lapisan masyarakat.

Tulang kambing merupakan salah satu alternatif sumber bahan baku menghasilkan gelatin yang potensial. Ekstraksi gelatin dari tulang kambing dapat dilakukan secara kimia (asam atau basa) dan enzimatik. Ekstraksi secara enzimatik biasa menggunakan protease, baik alami maupun komersil seperti alcalase, neutrase, enzim pepsin, dan enzim bromelin (Zhang et al., 2019 ; Norziah et al., 2014 ; Lassoued et al., 2014). Protease memiliki kemampuan mendukung perubahan protein tertentu dan sangat spesifik, misalnya dengan kondisi hidrolisis tertentu dapat menghasilkan protein dengan sifat fungsional yang berbeda, yang berperan menentukan sifat dan fungsi penggunaan produk akhir yang dihasilkan (Sumantha et al., 2006).
Penelitian ekstraksi gelatin dengan menggunakan enzim protease telah banyak dilakukan, dan umumnya untuk menghasilkan protein hidrolisis dengan berbagai aktivitas biopeptida pada kulit hewan atau tulang ikan (Lassoued et al., 2015 ; Imelda et al., 2017 ; Huang et al., 2018 ; Saadaoui et al., 2019), dan khusus penggunaan enzim neutrase untuk ekstraksi tulang kambing Kacang untuk menghasilkan gelatin masih jarang diteliti. Penelitian ini dilakukan untuk mengevaluasi kemampuan neutrase dengan beberapa konsentrasi enzim dalam mengekstraksi tulang kambing Kacang untuk menghasilkan gelatin dengan karakteristik gel untuk aplikasi pangan dengan mengidentifikasi kadar abu, air, lemak dan protein, yield, kekuatan gel, $\mathrm{pH}$, viskositas serta gugus fungsional Fourier Transform Infrared Spectrofotometri (FTIR) gelatin.

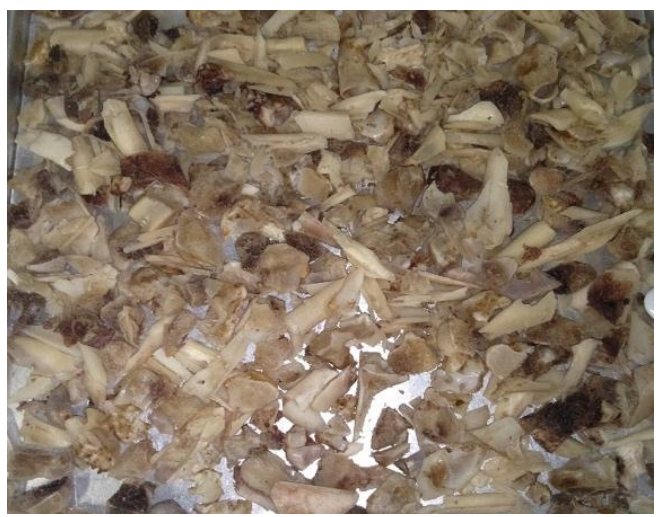

(b)

Gambar 1. Tulang kambing Kacang (belum dibersihkan (a), dan telah dikeringkan (b))

\section{BAHAN DAN METODE}

Bahan yang digunakan dalam penelitian ini adalah tulang yang berasal dari kambing Kacang umur 6 sampai 12 bulan diperoleh dari wilayah Wonogiri. Tulang kambing selanjutnya disimpan pada suhu -20 ${ }^{\circ} \mathrm{C}$ dan sebelum digunakan dicairkan pada suhu $4^{\circ} \mathrm{C}$ selama 12 jam. Neutrase ${ }^{\circledR}$ 0,8L (3.4.24.28) adalah metallo-endoprotease dari Bacillus amyloliquefaciens dengan aktivitas enzim $0,8 \mathrm{U} / \mathrm{g}$, diperoleh dari SigmaAldrich Chemical (St. Louis, MO, USA), $\mathrm{NaOH}$, EDTA $2 \mathrm{Na}$, buffer phosfat, buthyl alcohol.

Tulang kambing sebelum diekstraksi dibersihkan dari kontaminan permukaan, lemak dan daging yang masih menempel, dipotong untuk mengeluarkan sumsum, dikeringkan dengan oven pada suhu $40{ }^{\circ} \mathrm{C}$ selama 24 jam (Gambar 1), dan dilakukan pengecilan ukuran $(1 \mathrm{~cm})$ menggunakan lumpang besi, ditimbang serta dibagi sesuai keperluan analisis. Selanjutnya tulang kambing dilakukan analisis proksimat meliputi, kadar air, abu, protein dan lemak (AOAC, 2000).

Sebelum dilakukan ekstraksi, perlu dilakukan perlakuan awal untuk mendapatkan ossein dengan menghilangkan protein non kolagen, lemak dan mineral. Tulang kambing yang telah dikecilkan ukurannya direndam dalam $0,1 \mathrm{M} \mathrm{NaOH}$ dengan perbandingan larutan sampel/alkali 1:5 (w/v) selama 48 jam (larutan $\mathrm{NaOH}$ diganti setiap 12 jam). Selanjutnya tulang kambing direndam kembali dalam butil alkohol $10 \%$ (v/v) volume $10 \mathrm{ml}$ selama 48 jam (larutan butil alkohol diganti setiap 12 jam) dan kemudian dilanjutkan dekalsifikasi. Proses dekalsifikasi dilakukan dengan perendaman menggunakan 0,5 M larutan EDTA-2Na $(\mathrm{pH}=7,5) 10 \mathrm{ml}$ selama 72 jam, pelarut diganti setiap 12 jam, dan dicuci sampai mencapai $\mathrm{pH}$ netral (Lingling et al., 2018).

Neutrase dengan konsentrasi yang berbeda: 0 , $0,25,0,5$ dan $0,75 \%$ (v/w), dicampur dengan ossein (100 g) dan diinkubasi dengan buffer phosfat selama 2 jam, pada $\mathrm{pH} 8$ dan suhu $50{ }^{\circ} \mathrm{C}$ menggunakan waterbath. Setelah diinkubasi, campuran diatur pada $\mathrm{pH} 7$ dan kerja enzim dinonaktifkan dengan pemanasan pada suhu $90^{\circ} \mathrm{C}$ selama 10 menit. Selanjutnya campuran diekstraksi dengan air suling rasio $1: 5(\mathrm{w} / \mathrm{v})$ pada suhu $60^{\circ} \mathrm{C}$ selama 4 jam. Hasil ekstraksi disaring dua kali menggunakan kain katun dan kertas saring (whatman No. 4) untuk memisahkan endapan dari larutan. Kemudian larutan hasil penyaringan dikeringkan dengan oven (Memmert IN 55) pada suhu $50^{\circ} \mathrm{C}$ selama 
48 jam untuk mendapatkan gelatin. Gelatin dikumpulkan, ditimbang dan dihaluskan. Ekstraksi dilakukan sebanyak lima kali pengulangan. Gelatin hasil ekstraksi dari tulang kambing tanpa neutrase dinyatakan sebagai GTK-N0. Gelatin yang diberi perlakuan $0,25,0,5$ dan $0,75 \%$ neutrase per $100 \mathrm{~g}$ tulang masing-masing dinyatakan sebagai GTK-N1, GTK-N2 dan GTK-N3.

Jumlah gelatin kering yang dihasilkan dari proses ekstraksi dikenal dengan istilah yield. Perhitungan yield diperoleh menggunakan rumus mengikuti metode Ktari et al. (2014) :

Yield $(g / 100 \mathrm{~g})=\frac{\text { Berat berat kering gelatin }(\mathrm{g})}{\text { Berat berat basah tulang }(\mathrm{g})} \times 100 \%$

\section{Karakterisasi gelatin tulang kambing Kacang dan Analisis Data}

Hasil gelatin yang diperoleh dari ekstraksi tulang kambing Kacang menggunakan enzim neutrase pada konsentrasi yang berbeda selanjutnya dilakukan karakterisasi meliputi analisis proksimat, $\mathrm{pH}$, kekuatan gel, viskositas serta gugus fungsional Fourier Transform Infrared Spectrofotometri (FTIR).

Analisis proksimat. Analisis proksimat gelatin, meliputi kadar air $(950,46)$, abu $(920.153)$, dan lemak (960,39). Kandungan protein (984.13) ditentukan berdasarkan kandungan nitrogen menggunakan metode Kjeldahl (AOAC, 2000). Faktor konversi nitrogen untuk tulang 6,25 dan gelatin 5,55.

pH. Nilai $\mathrm{pH}$ gelatin ditentukan mengikuti metode See et al. (2010), dengan sedikit modifikasi. Gelatin kering sebanyak 0,667 g dilarutkan dalam $10 \mathrm{ml}$ air suling pada $60^{\circ} \mathrm{C}$ selama 30 menit menggunakan magnetik stirer IKA ${ }^{\circledR}$ C-MAG HS 7. Larutan gelatin didinginkan pada suhu kamar selama 30 menit, dan diukur nilai $\mathrm{pH}$ menggunakan $\mathrm{pH}$ meter HI 2210 pada $25^{\circ} \mathrm{C}$. Sebelumnya, $\mathrm{pH}$ meter telah distandarisasi dengan buffer $\mathrm{pH}$ 4, 7 dan 10 .

Kekuatan gel. Pengujian kekuatan gel gelatin mengikuti metode Lassoued et al. (2014). Larutan gelatin dengan konsentrasi 6,67\%(w/v), dibuat dengan

Tabel 1. Komposisi Kimia Tulang Kambing Kacang melarutkan 6,67 g sampel dalam $100 \mathrm{ml}$ aquades pada suhu $60^{\circ} \mathrm{C}$ selama 15 menit (gelatin larut secara sempurna). Selanjutnya larutan diinkubasi pada suhu $7^{\circ} \mathrm{C}$ selama 16-18 jam hingga berbentuk gel. Sampel gelatin dalam wadah diletakkan tepat pada bagian bawah plunger universal texture machine dengan kecepatan probe $1 \mathrm{~mm} /$ menit dan kedalaman tekanan 4 $\mathrm{mm}$. Diameter plunger yang digunakan adalah $12,7 \mathrm{~mm}$ (luas permukaan plunger $=126,728 \mathrm{~mm}^{2}$ ). Hasil pembacaan maksimum yang diberikan plunger pada gel merupakan Fmax sampel. Perhitungan kekuatan gel dalam satuan g bloom dengan menggunakan rumus:

Kekuatan gel $(\mathrm{g}$ bloom $)=$ Gaya maks $\left(\frac{\mathrm{g}}{\mathrm{mm}^{2}}\right) \times$ Luas permukaan plunger $\left(\mathrm{mm}^{2}\right)$

Viskositas. Viskositas gelatin diukur dengan menggunakan alat viskometer mengikuti metode Koli, et al. (2018). Larutan gelatin pada konsentrasi 6,67\% (w/v) dibuat dengan melarutkan bubuk kering dalam air suling dan dipanaskan pada suhu $60^{\circ} \mathrm{C}$ untuk penentuan viskositas. Viskositas (cP) dari $10 \mathrm{ml}$ larutan ditentukan menggunakan viskometer Brookfield yang dilengkapi dengan spindle 61 pada kecepatan $60 \mathrm{rpm}$.

Analisis Spektrokopis fourier transform infrared (FTIR). Struktur gelatin dianalisis spektra FTIR menggunakan spektrometer Perkin Spectrum One (Shimadzu prestige 21), dengan metode teknik preparasi pellet $\mathrm{KBr}$ (Kalium Bromide). Sampel dan $\mathrm{KBr}$ dicampur pada rasio 1: 100 untuk mengukur spektrum absorbansi dari 650 hingga $4000 \mathrm{~cm}^{-1}$. Sinyal spektrum dikumpulkan dalam 36 pemindaian dengan resolusi $16 \mathrm{~cm}^{-1}$. Analisis data spektral dilakukan dengan menggunakan perangkat lunak ((Sastrohamidjojo, 2001).

Penelitian ini menggunakan Rancangan Acak Lengkap (RAL) pola searah, yang dianalisis menggunakan ANOVA dan dilanjutkan dengan uji lanjut Duncan (DMRT) pada tingkat kepercayaan 95\% (Steel dan Torrie, 1993). Data yang diperoleh dianalisis dengan SPSS versi 21.

\begin{tabular}{lccccc}
\hline \multirow{2}{*}{ Sampel } & \multicolumn{5}{c}{ Komposisi (\%) } \\
\cline { 2 - 6 } & Air & Abu & Protein & Lemak & Referensi \\
\hline Tulang kambing & $9,19 \pm 0,06$ & $49,43 \pm 0,13$ & $22,12 \pm 0,20$ & $10,10 \pm 0,36$ & \\
Kacang & $59,58 \pm 0,68$ & $9,54 \pm 1,44$ & $20,28 \pm 0,87$ & $10,42 \pm 0,91$ & Abedinia, et al., 2017 \\
Tulang kaki bebek & 44,48 & 12,62 & 30,77 & 6,55 & Sanaei, et al. 2013 \\
Tulang ikan Lele & 60.66 & 6,65 & 18,69 & 5,7 & Bichukale et al., 2018 \\
Tulang kaki ayam & 10,8 & - & 29,5 & - & Ferraro, et al., 2017 \\
Tulang sapi & & & & &
\end{tabular}




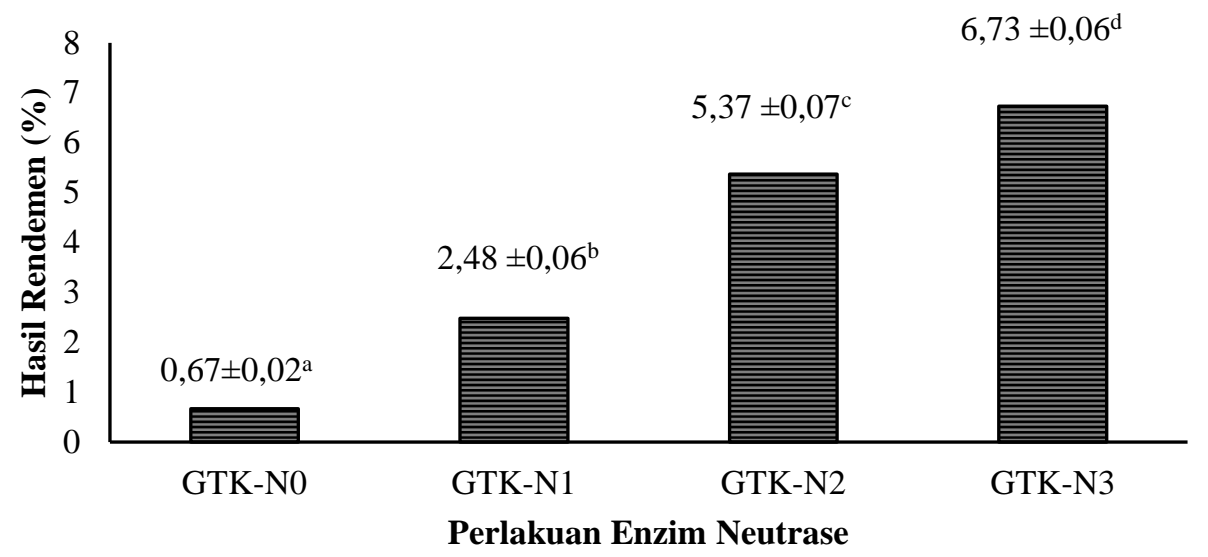

Gambar 2. Yield Gelatin Tulang Kambing Kacang Pada Konsentrasi Enzim Neutrase yang Berbeda

\section{HASIL DAN PEMBAHASAN}

\section{Komposisi Kimia Tulang Kambing Kacang}

Hasil analisis proksimat tulang kambing Kacang dam beberapa ternak lainnya ditunjukan pada Tabel 1 . Komposisi kimia tulang kambing Kacang dalam penelitian ini memiliki kadar abu yang dominan pada tulang yaitu 49,43 $\pm 0,13$, bila dibandingkan dengan spesies ternak lainnya, selanjutnya diikuti protein, lemak dan air. Hal ini sejalan dengan Moreno-Piraján et al. (2011), dimana komposisi tulang terdiri dari sekitar $60 \%$ komponen anorganik (hidroksiapatit), 10\% air dan $30 \%$ komponen organik (protein matriks tulang). Komponen protein organik tulang sebagian besar terdiri dari kolagen tipe I (90\%). Dari komposisi kimia tulang kambing, kandungan protein kasar berada di bawah tulang ikan lele dan tulang sapi, namun masih lebih tinggi jika dibandingkan dengan tulang kaki ayam dan bebek peking. Kandungan protein kasar dapat digunakan sebagai indikator kemurnian hidrolisat protein (See et al., 2010).

\section{Yield Gelatin}

Yield gelatin hasil ekstraksi tulang kambing Kacang menggunakan enzim Neutrase dengan konsentrasi yang berbeda dapat dilihat pada Gambar 2. Penggunaan enzim Neutrase dalam penelitian ini secara signifikan berpengaruh nyata $(\mathrm{P}<0,05)$ untuk meningkatkan yield gelatin seiring dengan meningkatnya jumlah enzim yang digunakan. Hal ini disebabkan karena enzim bekerja membantu pembengkakan dan pembukaan ikatan silang. Semakin tinggi konsentrasi enzim, maka semakin tinggi aktivitas kerja enzim dan semakin banyak peptida dapat dipotong selama substrak masih tersedia.

Yield tertinggi dari ekstraksi tulang kambing Kacang oleh enzim neutrase terdapat pada perlakuan GTK-N3 yaitu sebesar 6,73 $\pm 0,06$ g gelatin kering per $100 \mathrm{~g}$ ossein dalam keadaan basah. Hasil tersebut hampir mirip dengan penelitian gelatin kaki bebek peking perlakuan awal enzimatik adalah 5,75\% (Abedinia et al., 2017), berbagai jaringan kaki ayam 5,97-7,84\% (Almeida dan Lannes, 2013) dan lebih rendah bila dibandingkan dengan gelatin ekstraksi tulang kambing tanpa enzim pada temperatur 60 sampai $100{ }^{\circ} \mathrm{C}$ selama 6 jam dan waktu curing 50 hari yaitu sebesar 21,19\% (Bahar et al., 2018). Perbedaan persentase gelatin yang diperoleh dipengaruhi oleh spesies dan umur hewan, komposisi proksimat, kandungan kolagen, tingkat ikatan silang bahan baku dan metode ekstraksi (Songchotikunpan et al., 2008; Widyasari dan Rawdkuen, 2014). Lamanya waktu perlakuan awal menyebabkan semakin lama waktu yang tersedia untuk menguraikan struktur triple helix rangkap tiga, maka semakin banyak jumlah kolagen yang diekstraksi dan dapat dikonversi menjadi gelatin. Proses ekstraksi gelatin dari tulang kambing Kacang pada penelitian ini, mulai dari perlakuan awal sampai proses ekstraksi membutuhkan waktu hanya 10 hari, pada suhu 50 sampai $60{ }^{\circ} \mathrm{C}$, bila dibandingkan dengan proses curing yang membutuhkan waktu lama (50 hari) dan suhu yang lebih tinggi.

\section{Karakteristik Kimia Gelatin}

Hasil analisis proksimat gelatin tulang kambing Kacang yang diekstraksi menggunakan neutrase dengan konsentrasi yang berbeda tersaji pada Tabel 2 .

Kadar air dalam bahan pangan sangat penting karena dapat mempengaruhi tekstur dan menentukan masa simpan terhadap kerusakan oleh mikroba. Kadar air gelatin kontrol dan dengan penggunaan neutrase hingga $0,75 \%$ tidak berbeda, dengan nilai rata-rata $10,12 \%$, lebih rendah dengan gelatin tulang ikan lele, yaitu sebesar 11,43\% (Sanaei et al., 2013). Kadar air gelatin masih memenuhi standar kualitas gelatin yang ditentukan yaitu maksimum 18\% (GMIA, 2012), dan $16 \%$ untuk gelatin yang dapat dimakan. 
Tabel 2. Hasil Analisis Proksimat Gelatin Ekstraksi Tulang Kambing Kacang dengan Enzim Neutrase

\begin{tabular}{lcccc}
\hline \multirow{2}{*}{ Sampel } & \multicolumn{4}{c}{ Proksimat } \\
\cline { 2 - 5 } & Air $(\%)^{\mathrm{NS}}$ & Abu $(\%)^{*}$ & ${\text { Protein }(\%)^{*}}^{\left.\text {Lemak }^{*} \%\right)^{\mathrm{NS}}}$ \\
\hline GTK-N0 & $10,23 \pm 0,18$ & $25,31 \pm 0,01^{\mathrm{a}}$ & $30,29 \pm 0,03^{\mathrm{a}}$ & $0,81 \pm 0,08$ \\
GTK-N1 & $10,05 \pm 0,08$ & $3,05 \pm 0,31^{\mathrm{b}}$ & $69,94 \pm 0,04^{\mathrm{c}}$ & $0,76 \pm 0,08$ \\
GTK-N2 & $10,05 \pm 0,03$ & $2,66 \pm 0,28^{\mathrm{b}}$ & $69,78 \pm 0,01^{\mathrm{c}}$ & $0,76 \pm 0,08$ \\
GTK-N3 & $10,20 \pm 0,01$ & $2,52 \pm 0,60^{\mathrm{b}}$ & $69,36 \pm 0,21^{\mathrm{b}}$ & $0,69 \pm 0,02$ \\
\hline
\end{tabular}

* huruf berbeda pada kolom yang sama menunjukkan berbeda nyata pada taraf 5\% uji DMRT

NS menunjukkan tidak berbeda nyata pada taraf $5 \%$ uji DMRT

Kadar abu gelatin dengan perlakuan enzim neutrase berkisar antara $2,52-3,05 \%$ dan menurun signifikan $(\mathrm{P}<0,05)$ dibandingkan kontrol, hal ini dapat disebakan karena enzim juga dapat digunakan untuk demineralisasi. Penggunaan enzim pada perlakuan awal pembuatan gelatin dilakukan oleh Ma et al. (2019) menggunakan pepsin dan menunjukan hasil yang lebih baik, mengurangi waktu ekstraksi dan gelatin yang diperoleh memiliki sifat fisikokimia yang sama dengan cara konvensinal. Kadar abu gelatin sampel lebih tinggi dari kadar abu tulang kaki ayam dengan perlakuan awal secara alkali oleh Rahman dan Jamalulail (2012) sebesar $1,56 \%$ dan lebih rendah bila dibandingkan dengan kadar abu gelatin tulang skapula sapi aceh (4,67 $\%$, yang dilaporkan Jelita et al. (2018) dengan demineralisasi selama delapan hari dan diekstraksi asam.

Kadar protein gelatin dengan perlakuan enzim meningkat signifikan $(\mathrm{P}<0,05)$ dibanding tanpa enzim, dengan nilai berkisar antara 69,36-69,94\%. Hal ini karena enzim mampu mendegradasi struktur protein menjadi rantai peptida penyusun asam amino, tetapi pada konsentrasi tertentu (maksimal) enzim tidak lagi mendegradasi struktur protein melainkan mendenaturasi protein yang mengakibatkan penurunan kadar protein. Hasil ini lebih lebih tinggi bila dibandingkan dengan gelatin tulang kaki ayam sebesar 67,4\% (Rahman dan Jamalulail, 2012) dan lebih rendah bila dibandingan dengan penelitian Akagündüz et al, (2014) pada gelatin tulang ikan air tawar dengan perlakuan enzim sebesar $80 \%$.

Proses pembuangan lemak merupakan salah satu perlakuan awal dari ekstraksi gelatin dengan tujuan untuk mendapatkan hasil gelatin yang optimal. Kadar lemak sampel berkisar antara 0,69 sampai tertinggi $0,81 \%$, menunjukan pembuangan lemak tulang dilakukan secara efisien. Kandungan lemak yang rendah dapat mempertahankan stabilitas sampel selama penyimpanan dan menentukan kualitas gelatin (See $e t$ al., 2010 ; Jellouli et al., 2011).

Tabel 3. Karakteristik pH, Kekuatan Gel dan Viskositas Gelatin Tulang Kambing Kacang

\begin{tabular}{lccc}
\hline & \multicolumn{3}{c}{ Komponen } \\
\cline { 2 - 4 } & $\mathrm{pH}^{*}$ & ${\text { Kekuatan gel }(\mathrm{g} \text { bloom })^{*}}^{\text {Sampel }}$ & Viskositas $(\mathrm{cP})^{*}$ \\
\hline GTK-N0 & $7,15 \pm 0,05^{\mathrm{a}}$ & $81,39 \pm 2,0^{\mathrm{a}}$ & $0,65 \pm 0,06^{\mathrm{a}}$ \\
GTK-N1 & $6,79 \pm 0,89^{\mathrm{b}}$ & $82,38 \pm 0,37^{\mathrm{b}}$ & $2,95 \pm 0,15^{\mathrm{c}}$ \\
GTK-N2 & $6,86 \pm 0,11^{\mathrm{b}}$ & $77,63 \pm 0,32^{\mathrm{b}}$ & $2,85 \pm 0,30^{\mathrm{c}}$ \\
GTK-N3 & $6,89 \pm 0,06^{\mathrm{b}}$ & $67,75 \pm 2,71^{\mathrm{b}}$ & $2,03 \pm 0,15^{\mathrm{b}}$ \\
\hline
\end{tabular}

huruf berbeda pada kolom yang sama menunjukkan berbeda nyata pada taraf 5\% uji DMRT

\section{Karakteristik Kualitas Fisik Gelatin}

Hasil analisis $\mathrm{pH}$, kekuatan gel dan viskositas gelatin tulang kambing Kacang tersaji pada Tabel 3. Penggunaan neutrase menghasilkan penurunan nilai $\mathrm{pH}$ dan peningkatan nilai kekuatan gel serta viskositas dari gelatin yang dihasilkan di bandingkan dengan kontrol secara signifikan $(\mathrm{P}<0,05)$. Penggunaan enzim neutrase hingga $0,75 \%$ menghasilkan gelatin dengan nilai $\mathrm{pH}$ berkisar 6,79 - 6,89, kekuatan gel (g bloom) 67,75 82,38 dan Viskositas sebesar 2,03 - 2,95.

$\mathrm{pH}$ gelatin yang diekstraksi menunjukan bahwa gelatin yang dihasilkan termasuk tipe $\mathrm{B}$ dengan nilai berkisar antara 5 - 7,5 (SNI, 1995). Nilai pH gelatin sangat ditentukan oleh perlakuan awal sebelum ekstraksi gelatin, dan netralisasi selama tahapan perlakuan awal yang dilakukan tidak sempurna. Penelitian ini menggunakan perlakuan alkali mulai dari perakuan awal sampai proses ekstraksi. Perbedaan nilai pH gelatin dapat disebabkan oleh jenis dan kekuatan bahan kimia yang digunakan selama proses perlakuan awal (Songchotikunpan et al., 2008; Shyni et al., 2014). Perbedaan $\mathrm{pH}$ kontrol terhadap sampel yang diberi perlakuan, juga dapat disebabkan kondisi $\mathrm{pH}$ ekstraksi enzim neutrase yaitu pada $\mathrm{pH}$ 8. Bahar et al. (2018) melaporkan bahwa $\mathrm{pH}$ gelatin tipe $\mathrm{B}$ dari tulang 
kambing bervariasi antara 6,25 - 8,65, gelatin kulit dan kaki ayam masing-masing 6,1 dan 6,8 (Kim et al., 2012; Widyasari dan Rawdkuen, 2014).

Kekuatan gel dan viskositas adalah sifat fisik penting bagi gelatin komersial yang berhubungan dengan berat dan distribusi molekul protein (Regenstein dan Zhou, 2007). Kekuatan gel dan viskositas sampel GTK-N1 lebih tinggi yaitu 82,38 $\pm 0,37 \mathrm{~g}$ bloom dan $2,95 \pm 0,15 \mathrm{cP}$, bila dibandingkan dengan sampel lain. Hal tersebut juga diikuti dengan tingginya kandungan protein gelatin (tabel 2). Proses pembentukan gel protein membutuhkan pembukaan struktur protein asli pada awal, dan selanjutnya diikuti dengan rantai-rantai protein (peptida), sehingga proses pembentukan gel membutuhkan protein dengan rantai besar sebagai bahan baku (Sanchez dan Burgos dalam Tavano, 2013). Selanjutnya Damrongsakkul et al. (2008) menemukan bahwa kulit mentah yang dihidrolisis dengan papain dan neutrase, produk papain yang memiliki rantai peptida yang lebih panjang menghasilkan gelatin dengan kekuatan dan viskositas gel, dan neutrase menghasilkan gelatin dengan viskositas sangat rendah.

Kekuatan gel dan viskositas dari beberapa penelitian yang menunjukan angka yang cukup bervariasi. Ma et al. (2019) menemukan kekuatan gel dan viskositas gelatin tulang babi dengan metode biokatalis, masing-masing adalah 162 - $287 \mathrm{~g}$ (bloom) dan 3,43 - 4,93 mp.s., selanjutnya 43,39 - 49,75 g (bloom) dan 19,60 - 21,20 pada gelatin tulang sapi proses curing dengan alkali (Bahar et al., 2018). Nilai kekuatan gel yang ditemukan pada penelitian ini masih berada pada standar yang ditentukan yaitu $50-300 \mathrm{~g}$ bloom (GMIA, 2012).

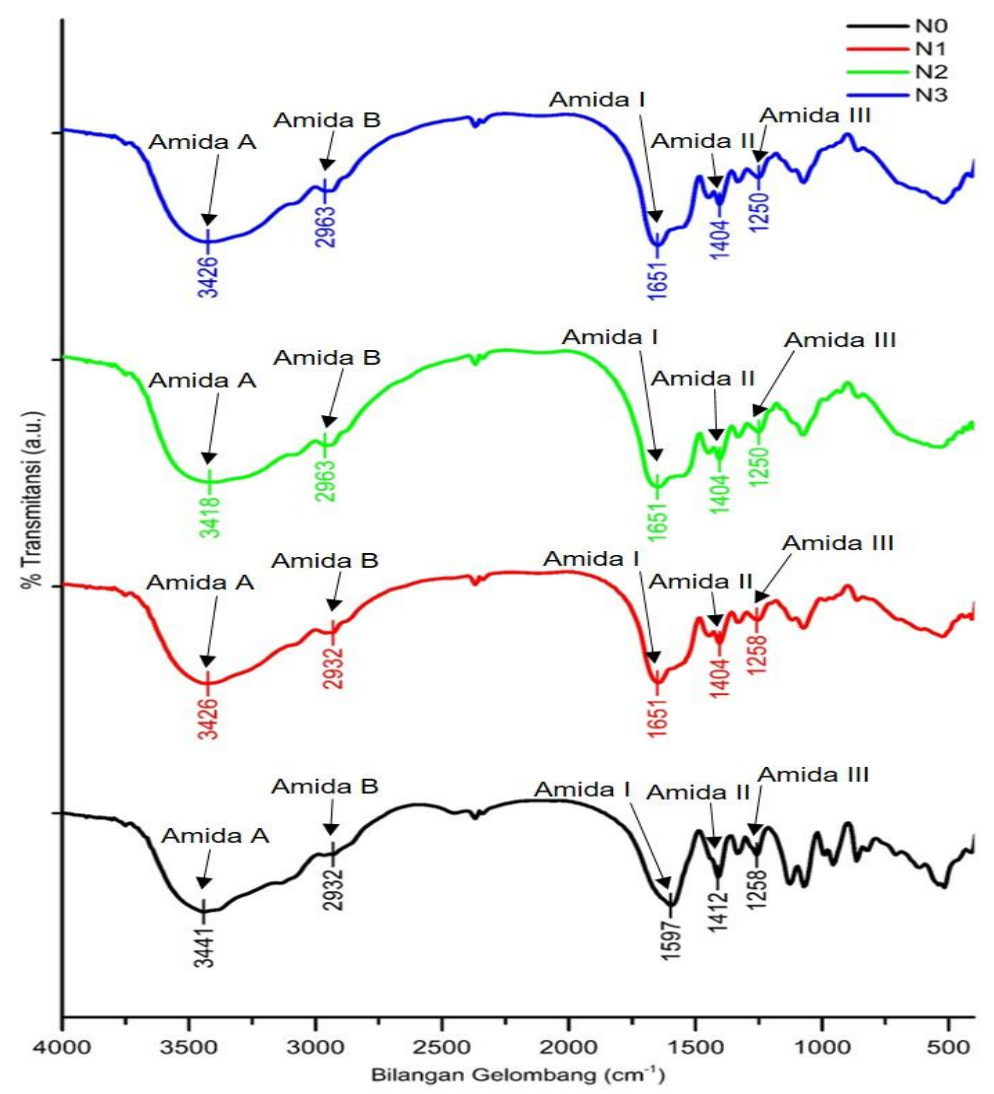

Gambar 3. Spektrokopis Fourier Transform Infrared Gelatin Tulang Kambing

Gugus fungsional Spektrokopis fourier transform infrared (FTIR) gelatin. Spektrum FTIR dari gelatin tulang kambing Kacang dengan konsentrasi yang berbeda ditunjukan pada Gambar 3. Spektroskopi digunakan untuk melihat gugus fungsional dan struktur gelatin sekunder (Cebi et al., 2016).

Pita amida A muncul pada semua sampel GTKN0, GTK-N1, GTK-N2 dan GTK_N3 dengan bilangan gelombang masing-masing 3441; 3426; 3418 dan 3426 $\mathrm{cm}-1$ bergeser ke bilangan yang semakin menurun. Namun mulai naik pada GTK-N3. Amida A mewakili perenggangan $\mathrm{N}-\mathrm{H}$ ditambah dengan ikatan hydrogen yang dapat diamati pada kisaran gelombang 3400-3440 $\mathrm{cm}_{1}$ (Muyonga et al., 2004). Bergesernya posisi pita ke frekuensi yang lebih rendah, menunjukkan bahwa terjadi ikatan hidrogen antara kelompok N-H dari fragmen peptida yang lebih pendek (Ahmad dan Benjakul, 2011). Hasil tersebut sejalan dengan penelitian Abedinia et al., 2017 pada gelatin kaki bebek peking didapati bahwa Gelatin yang diekstraksi enzimatik menunjukkan puncak intensif yang bergeser ke angka gelombang yang lebih rendah, yang mengindikasikan perubahan struktur kolagen sekunder. Pita amida B pada sampel GTK-N0 dan GTK-N1 
muncul pada bilangan gelombang yang sama yaitu 2932 $\mathrm{cm}^{-1}$ dan $2963 \mathrm{~cm}^{-1}$ untuk sampel GTK-N2 dan GTK$\mathrm{N} 3$, sesuai dengan bentangan asimetris $\mathrm{CH} 2$ diamati pada bilangan gelombang 2925-2965 cm-1 (Muyonga et al., 2004).

Bilangan gelombang amida I, amida II dan amida III secara langsung berhubungan dengan konfigurasi kolagen (Heu et al., 2010). Pita Amida 1 gelatin GTK-NO muncul pada bilangan gelombang $1597 \mathrm{~cm}^{-1}$ dan GTK-N1, GTK-N2 dan GTK-N3 menunjukan bilangan gelombang yang sama yaitu 1651 $\mathrm{cm}^{-1}$. Hal ini terutama berhubungan dengan getaran perenggangan $\mathrm{C}=\mathrm{O}$ sepanjang punggung polipeptida dalam kisaran 1680-1630 cm-1 (Muyonga et al., 2004). Penyerapan di wilayah amida I penting dalam analisis spektroskopi inframerah untuk struktur sekunder protein, sebab merupakan karakteristik fungsional gelatin (Nagarajan et al., 2012). Pita amide-II menunjukkan getaran lentur kelompok $\mathrm{N}-\mathrm{H}$ dan getaran peregangan kelompok $\mathrm{C}-\mathrm{N}$, tidak dijunjukkan pada semua sampel gelatin tulang kambing, tetapi getaran lentur $\mathrm{CH}_{2}$ dengan puncak bilangan gelombang $1412 \mathrm{~cm}^{-1}$ pada sampel GTK-N0, sedangkan GTK-N1, GTK-N2, GTK-N3 memiliki puncak gelombang yang sama yaitu 1404,18 cm -1 (Abedinia et al., 2017). Pita amida III dihubungkan dengan deformasi $\mathrm{N}-\mathrm{H}$ dan getaran peregangan $\mathrm{C}-\mathrm{N}$ muncul pada semua sampel gelatin. Sampel GTK-NO dan GTK-N0 menunjukkan bilangan gelombang yang sama yaitu $1258 \mathrm{~cm}^{-1}$, dan GTK-N2 dan GTK-N3 juga memiliki bilangan gelombang yang sama yaitu $1250 \mathrm{~cm}^{-1}$.

\section{SIMPULAN}

Hasil penelitian menyimpulkan (1) neutrase dapat digunakan untuk ekstraksi tulang kambing Kacang dan konsentrasi $0,25 \%$ berpengaruh terhadap karakteristik kimia dan fisik gel, dan (2) gelatin tulang kambing Kacang yang diekstraksi dengan neutrase memiliki karakteristik yang dapat diaplikasikan ke pangan.

\section{DAFTAR PUSTAKA}

Abedinia, A., Ariffin, F., Huda, N. and A. M. Nafchi. 2017. Extraction and characterization of gelatin from the feet of Pekin duck (Anas platyrhynchos domestica) as affected by acid, alkaline, and enzyme pretreatment. International Journal of Biological Macromolecules, 98: 586-594.

Ahmad, M. and Benjakul, S. 2011. Characteristics of gelatin from the skin of unicorn leatherjacket (Aluterusmonoceros) as influenced by acid pretreatment and extraction time. Food Hydrocolloids, 25(3): 381- 388.

Akagündüz, Y., Mosquera, M., Giménez, B., Alemán, A., Montero,P. and M.C. Gómez-Guillén. 2014. Sea bream bones and scales as a source of gelatin and ACE inhibitory peptides. LWT - Food
Science and Technology, 55: 579-585.

Almeida, P.F. and S.C.D.S. Lannes. 2013. Extraction and physicochemical characterization of gelatin from chicken by-product, J. Food Process Eng., 36 (6): 824-833.

AOAC. 2000. Official Methods of Association official Analytical Chemist. $12^{\text {th }}$ edition. Publish by Association of Offical of Analytical Chemist.Benjamin Franklin Station. Washington D.C.

Bahar, A., Rusijo, and N. Kusumawati. 2018. The Effect of Curing and Extraction Time against Yield and Quality of Type B Gelatin from Goat Bone. Atlantis Highlights in Chemistry and Pharmaceutical Sciences, 1:5-9.

BPS. 2017. Badan Pusat Statustik Indonesia. www.bps.go.id. Diakses Agustus 2018.

Cebi, C., Durak, M.Z., Toker, O.S., Sagdic, O. and M. Arici. 2016. An evaluation of Fourier transforms infrared spectroscopy method for the classification and discrimination of bovine, porcine and fish gelatins, Food Chemistry, 190: $1109-1115$.

Damrongsakkul, S., K. Ratanathammapan, K. Komolpis, and W. Tanthapanichakoon. 2008. Enzymatic hydrolysis of rawhide using papain and neutrase. Journal of Industrial and Engineering Chemistry. 14(2): 202-206. https://doi.org/10.1016/j.jiec.2007.09.010.

Gelatin Manufacturers Institute of America (GMIA). 2012. Gelatin Handbook. Gelatin Manufacturers Institute of America, Inc, New York.

Heu, M.S., Lee, J.H., Kim, H.J., Jee, S. J., Lee, J.S., Jeon, Y.J., Shahidi, F. and J. Kim. 2010. Characterization of acid- and pepsin-soluble collagens from flatfish skin. Food Science and Biotechnology, 19(1): 27-33.

Huang, C., Tsai, Y., Hong, Y., Hsieh, S. and R. Huang. 2018. Characterization and Antioxidant and Angiotensin I-Converting Enzyme (ACE)Inhibitory Activities of Gelatin Hydrolysates Prepared from Extrusion-Pretreated Milkfish (Chanos chanos) Scale. Marine Drugs, 16, 346; doi:10.3390/md16100346.

Imelda, W.Y. Cheung, Eunice C.Y. Li-Chan. 2017. Enzymatic production of protein hydrolysates from steelhead (Oncorhynchus mykiss) skin gelatin as inhibitors of dipeptidyl-peptidase IV and angiotensin-I converting enzyme. Journal of Functional Foods, 28: 254-264.

Jelita J, Wirjosentono, B.,Tamrin, T. and L. Marpaung. 2018 Characterization of gelatin from scapula (Os scapula ) from Aceh cattle. 
https://doi.org/10.1063/1.5082477.

Jellouli, K., Balti, R., Bougatef, A., Hmidet, N., Barkia, A., and M. Nasri. 2011. Chemical composition and characteristics of skin gelatin from grey triggerfish (Balistes capriscus). LWT - Food Science and Technology, 44: 1965-1970.

Kim, H.W., Song, D.H., Choi, Y.S., Kim, H.K., Hwang, K.E., Park, J.H., Kim, Y.J., Choi, J.H. and J. Kim. 2012. Effects of soaking $\mathrm{pH}$ and extracting temperature on the physicochemical properties of chicken skin gelatin. Korean J. Food Sci. Anim. Resour, 32: 316-322.

Koli, J.M., Sonavane, A.E., Vishwasrao, V. dan K.H. Pujari. 2018. Functional Properties of Gelatin Extracted From Poultry Skin and Bone Waste. International journal Pure Application Biosci, 6 (4): $87-101$.

Ktari, N., Bkhairia, .I, Jridi, M., Hamza, I., Riadh, B. S. and M. Nasri. 2014. Digestive acid protease from zebra blenny (Salaria basilisca): Characteristics and application in gelatin extraction. Food Research International, 57: 218-224.

Lassoued, I, Jridi, M., Nasri, R., Dammak, A., Hajji, M., Nasri, M. and A. Barkia. 2014. Characteristics and functional properties of gelatin from thornback ray skin obtained by pepsin-aided process in comparison with commercial halal bovine gelatin. Food Hydrocolloids, 41: 309318.

Lassoued, I., Mora, L., Barkia, A., Aristoy, M.-C., Nasri, M., and F. Toldrá. 2015. Bioactive peptides identified in thornback ray skin's gelatin hydrolysates by protease from Bacillus subtilis and Bacillus amyloliquefaciens. Journal of Proteomics, 128: 8-17.

Ling-ling, G., Zhen-yu, W., Zheng, L., Cai-xia, Z. and Z. De-quan. 2018. The characterization of acid and pepsin soluble collagen from ovine bones (Ujumuqin sheep). Journal of Integrative Agriculture, 17(3): 704-711.

Liu, D, Liang, L, Regenstein, J.M. and P. Zhou. 2012. Extraction and characterisation of pepsinsolubilised collagen from fins, scales, skins, bones and swim bladders of bighead carp (Hypophthalmichthys nobilis). Food Chemistry, 133:1441-1448.

Ma, Y., Zeng, X., Ma, X., Yang, R. and W. Zhao. 2019 A simple and eco-friendly method of gelatin production from bone: One-step biocatalysis. Journal of Cleaner Production journal, 209: 916926.

Moreno-Piraján, J.C., Giraldo, L. and V.S. GarcíaCuello. 2011. Study of the textural properties of bovine bones char under different conditions $\mathbf{J}$.
Water Resour. Protein, 3 (3): 176-181.

Muyonga, J. H., Cole, C. G. B., and K.G. Duodu. (2004). Fourier transform infrared (FTIR) spectroscopic study of acid soluble collagen and gelatin from skins and bones of young and adult Nile perch (Lates niloticus). Food Chemistry, 86: 325-333.

Nagarajan, M., Benjakul, S., Prodpran, T., Songtipya, P. and H. Kishimura. 2012. Characteristics and functional properties of gelatin from splendid squid (Loligo formosana) skin as affected by extraction temperatures. Food Hydrocolloids, 29: 389-397.

Norziah, M., Kee, H. and M. Norita. 2014. Response surface optimization of bromelain-assisted gelatin extraction from surimi processing wastes, Food Biosci., 5: 9-18.

Rahman, M.N.A., and S.A.S.K.A. Jamalulail. (2012), Extractions, Physicochemical Characterizations and Sensory Quality of Chicken Feet Gelatin, Borneo Science, 30: 1-13.

Regenstein, J. and P. Zhou. 2007. Collagen and gelatine from marine by-products. In: Maximising the Value of Marine By-Products (edited by F. Shahidi). Cambridge: Woodhead Publishing Limited, 279-303.

Saadaoui, H., Espejo-Carpio, F.J., Guadix, E.M., Amar, R.B. and R. Pérez-Gálvez. 2019. Bi-objective optimization of tuna protein hydrolysis to produce aquaculture feed ingredients. Food and Bioproducts Processing, 115: 26-35.

Sanaei, A.V., Mahmoodani, F., See, S.F., ${ }^{*}$ Yusop, S.M. and A.S. Babji. 2013. Optimization of gelatin extraction and physico-chemical properties of catfish (Clarias gariepinus) bone gelatin. International Food Research Journal, 20(1): 423430 .

Sastrohamidjojo, H. 2001. Spektroskopi. Cetakan kedua. Liberty, Yogyakarta.

See, S. F., Hong, P. K., Ng, K. L., Aida W. M. and A. S. Babji. 2010. Physicochemical properties of gelatins extracted from skins of different freshwater fish species International Food Research Journal, 17: 809-816.

Shyni, K., Hema, G.S., Ninan, G., Mathew, S., Joshy, C.G. and P.T. Lakshmanan. 2014. Isolation and characterization of gelatin from the skins of skipjack tuna (Katsuwonus pelamis), dog shark (Scoliodon sorrakowah), and rohu (labeo rohita). Food Hydrocolloids, 39: 68-76.

Songchotikunpan, P., Tattiyakul, J., \& Supaphol, P. 2008. Extraction and Electro-Spinning of Gelatin from Fish Skin. International Journal of 
Biological Macromolecules, 42: 247 - 255.

Steel, R.G.D. and J.H. Torrie. 1993. Prinsip dan Prosedur Statistika, Suatu pendekatan Biometrik. Penerjemah: B. Sumantri. Gramedia Pustaka Utama, Jakarta.

Standar Nasional Indonesia (SNI). 1995. Mutu dan cara uji gelatin. SNI 01-3735. Jakarta.

Sumantha, A., Larroche, C., \& Pandey, A. (2006). Microbiology and industrial bio- technology of food-grade proteases: A perspective. Food Technology and Biotechnology, 44(2), 211-220.

Tavano, O.L. 2013. Protein hydrolysis using proteases:
An important tool for food biotechnology. Review. Journal of Molecular Catalysis B: Enzymatic, 90:1-11.

Widyasari, R. and S. Rawdkuen. 2014. Extraction and characterization of gelatin from chicken feet by acid and ultrasound assisted extraction, Food Appl. Biosci. J., 2 (1): 85-97.

Zhang, Y., Dutilleul, P., . Li, C. and B.K. Simpson. 2019. Alcalase-assisted production of fish skin gelatin rich in high molecular weight (HMW) polypeptide chains and their characterization for film forming capacity Lwt- Food Science and Technology, 110: 117-125.

Available online at journal homepage: http://ojs3.unpatti.ac.id/index.php/agrinimal 